\title{
深夜急行バスを対象とした 短期的需要予測に基づく配車計画の検討
}

\author{
川崎 智也 1 ・轟 $\quad$ 朝幸 2 - 岩崎 哲也 3 - 西内 裕晶 4 \\ 1正会員 日本大学助教 理工学部交通システム工学科（†274-8501 千葉県船橋市習志野台7-24-1） \\ E-mail: kawasaki.tomoya@nihon-u.ac.jp \\ 2正会員 日本大学教授 理工学部交通システム工学科（テ274-8501 千葉県船橋市習志野台7-24-1） \\ E-mail: todoroki.tomoyuki@nihon-u.ac.jp \\ 3 学生会員 日本大学大学院 理工学研究科社会交通工学専攻（干274-8501 千葉県船橋市習志野台7-24-1） \\ E-mail: cste12003@g.nihon-u.ac.jp \\ 4正会員 長岡技術科学大学助教 環境・建設系（广940-2188 新潟県長岡市上富岡町1603-1） \\ E-mail: nishiuchi@vos.nagaokaut.ac.jp
}

\begin{abstract}
深夜急行バスは利用者の変動が大きく, 配車台数の調整が難しい. しかしながら, バスの配車台数は金 曜・祝前日は2台，その他曜日は1台と，慣例的に決定されており，バスの供給不足・過多が発生している. 本研究では，1)深夜急行バスの利用要因をアンケート調查などにより明らかにし，2)利用者数の需要予測 に基づき配車台数予測を行い，3)バスの配車台数について効率性が向上したか検討することを目的とした。 ニューラルネットワークを用いた利用者予測モデルにより利用者数を予測し，バスの配車台数を見直した. その結果, 実データでは適切に配車した運行日の的中率は $89.6 \%$ であったが, 本研究で提案するモデルを 用いることで, 95.7\%まで的中率を増加させることができた.これより, 本研究で構築したモデルは効率 的なバスの配車計画に有用であると考えられる.
\end{abstract}

Key Words : midnight bus, demand forecasting, neural network, vehicle allocation

\section{1. はじめに}

深夜急行バスは路線バスなど他の公共交通機関と比較 して, 利用者数の変動が大きく, 需要に対する供給の調 整が難しいことが知られている. 利用者数が予測より多 い場合は, バスの配車台数不足による減収, 車内混雑や 待ち時間増大による利用者満足度の低下などの悪影響が 発生する．また，利用者数が予測より少ない場合は，乗 客は座席に座ることができ，利用者満足度が向上すると いう側面は存在するものの, ロードファクターが小さく なることにより, 乗客一人当たり運用費用の増大などの 悪影響が見込まれる，以上の背景より，バスの配車台数 (供給) は利用者数（需要）に応じて, 適切に調整する 必要がある.

しかしながら，深夜急行バスに関する研究はあまり進 んでいないのが現状である。森地ら”潧都圈において 深夜急行バスとタクシーの2機関分担モデルを構築し, 深夜の両輸送機関利用要因の分析を行った. 分析の結果, 深夜急行バスはタクシーの待ち時間が少ないほど利用さ
れないことを明らかにした。倉㴊・浅野2は新宿駅にて 深夜急行バス利用者を対象にアンケート調查を行い，金 曜日が最も利用される曜日であり, 曜日別の需要変動が 大きいことを明らかにした。 また，調査対象としたバス 会社では，金曜日は2台，それ以外の曜日では1台のバス を慣例的に配車しており，需要予測に基づいてバスの配 車台数を決定していないことについて述べている．いず れの研究においても, 深夜急行バス利用者数の予測や効 率的な配車台数に関する議論が行われていない.

そこで本研究では, 1)深夜急行バスの利用要因をアン ケート調查などにより明らかにし，2)利用者数の需要予 測に基づき配車台数予測を行い，3)バスの配車台数につ いて効率性が向上したか検討することを目的とする.

本研究の構成は以下の通りである. まず，2.で利用者 数の増加・減少要因と予測手法に関する既存研究の整理 を行う. 3.では, 本研究での対象路線について概説し, 深夜急行バスの利用に影響を与えると考えられる要因の 検討を, 対象路線のデータを用いた基礎集計及びアンケ 一ト調査より行う。4.では, 2.及び3.から特定された深 
夜急行バスに影響を与えると考えられる要因を入力值と して, 深夜急行バス利用者数をニューラルネットワーク （NN）を用いて推定する. NNで推定した予測值を用い て，5.でバスの配車台数予測を行い，バスの配車台数に ついて効率性が向上寸るかどうかを検討する. 最後に, 6.で本研究の結論及び今後の課題について述べる.

\section{2. 既存研究の整理}

\section{（1）利用者数変動要因に関する文献}

一般的に, 公共交通利用者数や自動車の交通量には, 変動が存在することが知られている3 では, 交通機関における利用者数変動要因に関連する研 究をレビューし，4.で実施する深夜急行バス利用者数予 測で用いる入力值を検討する.

交通機関における利用者数変動要因としては, 曜日が 影響することが知られている゙3. 全目的トリップ数は日 曜日が最も少なく, 月曜日から金曜日にかけては安定し て推移し，土曜日が最も多くなるのが通常である ${ }^{4)}$.た だし，トリップ目的によってはピークの矅日が異なるこ とが知られている．例えば，買い物トリップに着目する と, 木曜日のトリップ数が最少で, 土曜日と日曜日が最 多となる ${ }^{4)}$, 5).また, 高速道路の交通量においても曜日 変動が存在することが分かっているの。公共交通機関の 利用者数の変動については，曜日だけでなく季節が影響 を及ぼすことが分かっている3,6,8).

天候も公共交通利用者数に影響を及ぼす。Zhanら》は, 天候が交通量を増減する重要な要因となっていることか ら，公共交通計画の策定においては，天候の影響を考慮 すべきと主張している，また，高山・塩土9（，天候が バス利用者数に与える影響について分析し，晴天時は徒 歩や自転車で通勤・通学している726人のうち, 約200人 は雨天・降雪時にバスへ転換することを明らかにしてい る. このように, 晴天時と雨天・降雪時に交通行動が異 なることが分かっている.

以上より, 交通機関の需要変動には曜日, 季節, 天候 などが影響していると考えられ，4.で実施する深夜急行 バス利用者数の予測に考慮する必要があることが分かっ た. また，トリップ目的によって利用者数が異なること も分かった．また，深夜急行バスのトリップ目的は帰宅 行動が多いことから，深夜急行バスを利用する動機を調 査し，それをモデルに考慮する必要があると考えられる。

\section{（2）予測手法に関する文献}

交通需要などの予測手法については，主にニューラル ネットワーク (NN) , ベイジアンネットワーク (BN) が存在する．例えば，BN は予測対象である事象が発生
する確率を予測するため, 高速道路において，ある区間 で発生した突発事象を前後区間の交通状況から検知する 仕組みの構築に用いられているの. Zhang and Taylor'は, オーストラリアの高速道路で BN を突発事象の検知に適 用し，その検知率が約 $92 \%$, 高精度で検知できること を示した 9.しかし，BN では確率分布を仮定し，その 確率分布のカテゴリを定義する，そのため，連続值とは ならないため, 深夜急行バスの利用者数などの量的予測 には適していない ${ }^{10}$.

$\mathrm{NN}$ は量的予測に適しており ${ }^{11)}$, 様々な研究分野で用 いられている. 例えば, 米国オクラホマ州タルサでは, 都市交通局の月次公共交通利用者数データを用いて, NN による将来利用者数予測を行い, 高精度で予測可能 であることを示した ${ }^{12}$. また, 村野ら ${ }^{13}$ は, 高速道路で の交通事故件数予測に NN を適用し, 対象区間で発生し た交通事故 34 件中 25 件を的中させた。 奥嶋ら $\left.{ }^{14}\right)$ は，阪 神高速道路池田出入口を対象に, 2 時間先の流入交通量 の予測に NNを用いており，予測交通量と実交通量との 差を 15 台以内で予測し, 高精度で交通量の予測が可能 であることを示した．また，NN は観光における周遊行 動分析 ${ }^{15}$ にも適用されており, 様々な分野で適用されて いることが分かる.

以上のように，NN は量的予測手法として交通におけ る様々な研究分野に適用されており, 高精度での予測実 績が多数存在する. 以上より, 本研究においても, NN を用いて深夜急行バスの短期的需要予測を行うこととす る.

\section{3. 深夜急行バス利用要因の検討}

本章では，対象路線を概説した上で，深夜急行バスの 利用者数に影響を及ぼす要因を検討するため, 対象路線 の利用者数データを用いて曜日別，月別，天気別などの 利用者数実態を把握する. また, 対象路線の乗客を対象 としたアンケート調查を行い, 深夜急行バス利用要因な どを分析する. 以下では, 深夜急行バス事業者へのイン タビュー調査の結果及び対象路線の特徵を整理する.

\section{(1) 対象路線}

本研究では，国際興業株式会社が運行する池袋駅を始 発とする深夜急行バス6路線を対象とした。対象路線の 概要及び路線図をそれぞれ表-1, 図-1に示す.

本研究で対象とする路線は6路線であり, 出発のバス 停は全て池袋駅である. 終点は朝霞台, 新座, 和光市, 東浦和，中浦和，大宮駅の6駅で，運行時間は概ね 21 時間 である. 運行は平日のみで, 土曜, 日曜, 祝日は運行し ていない. バスは非予約制で立席も認められているが, 
表-1 対象路線の概要

\begin{tabular}{|c|c|c|c|c|}
\hline 始発駅 & 主要経由地 & 終点 & 出発時刻 & 運行時間 \\
\hline \multirow{4}{*}{ 池袋 } & 成増 & 朝霞台 & 1時05分 & 1時間01分 \\
\cline { 2 - 5 } & 志木 & 新座 & 1時20分 & 1時間15分 \\
\cline { 2 - 5 } & 光が丘 & 和光市 & 1時20分 & 45分 \\
\cline { 2 - 5 } & 南浦和 & 東浦和 & 1時20分 & 1時間24分 \\
\cline { 2 - 6 } & 高島平 & 中浦和 & 1時20分 & 1時間00分 \\
\cline { 2 - 6 } & 浦和 & 大宮 & 1時20分 & 1時間09分 \\
\hline
\end{tabular}

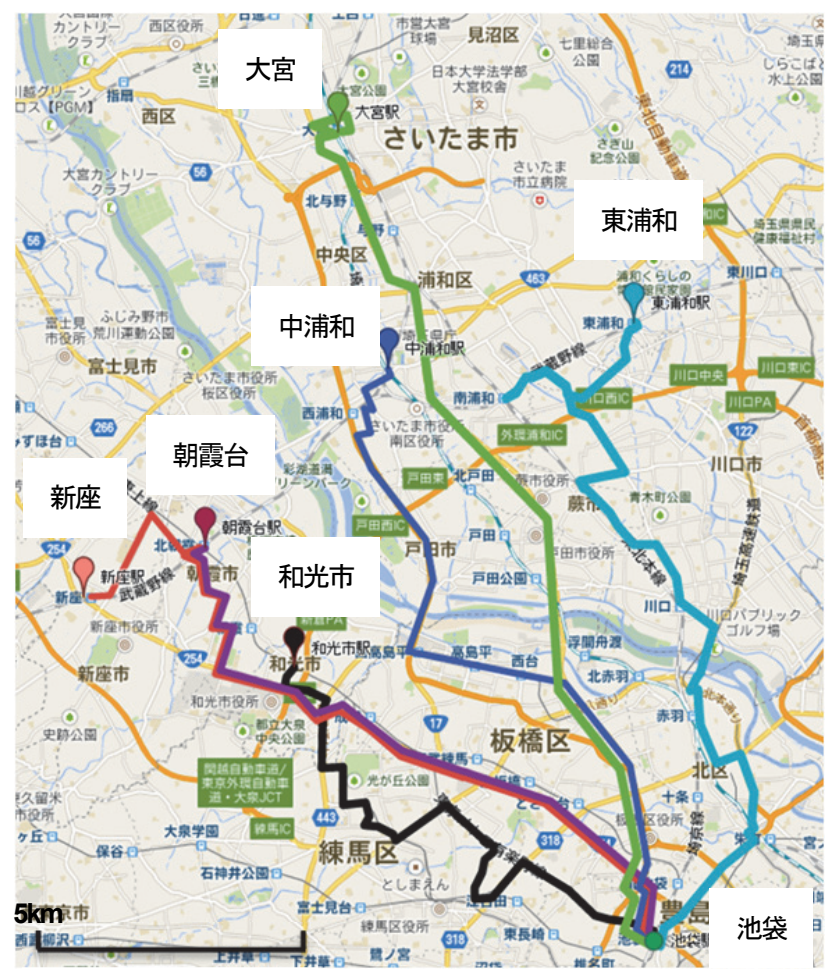

図-1 対象6路線の路線図

1台の定員は70名である.

出発時刻は池袋駅の各鉄道路線からの乗り継ぎを意識 して設定されており，各路線とも出発時刻は午前1時台 である．運行時間は概ね1時間で，和光市行きが45分で 最短である。なお，バスは池袋駅からの乗車のみ認めら れており，途中停車バス停からの乗車はできない.

国際興業株式会社へのインタビュ一調査によると，バ スの配車台数は，全路線において平日は1台，金曜・祝 前日は2台と慣例的に決められている.

\section{（2）利用者数データの基礎集計}

深夜急行バス利用者数への影響要因を検討するために， 対象6路線の2011年4月1日から2013年3月29日までの運行 日である493日の実利用者数を用いて基礎集計を行う. なお，2.(1)の文献調査において，曜日，季節（月）によ って利用者数に増減が見込まれることが示唆されたため, 曜日別一日当たり平均利用者数，月別一日当たり平均利 用者数を路線別にそれぞれ図-2, 図-3に示す。なお，実 利用者数データを公表することができないため，図-2で は月曜日，図-3では2011年4月の一日当たり平均利用者

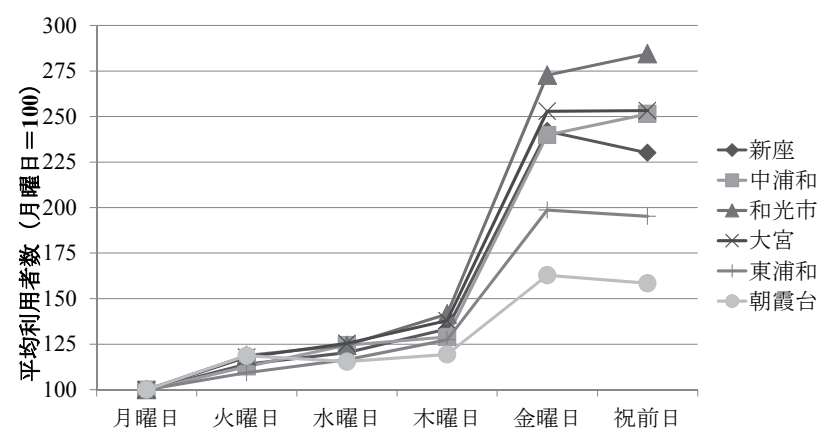

図-2 曜日別一日当たり平均利用者数

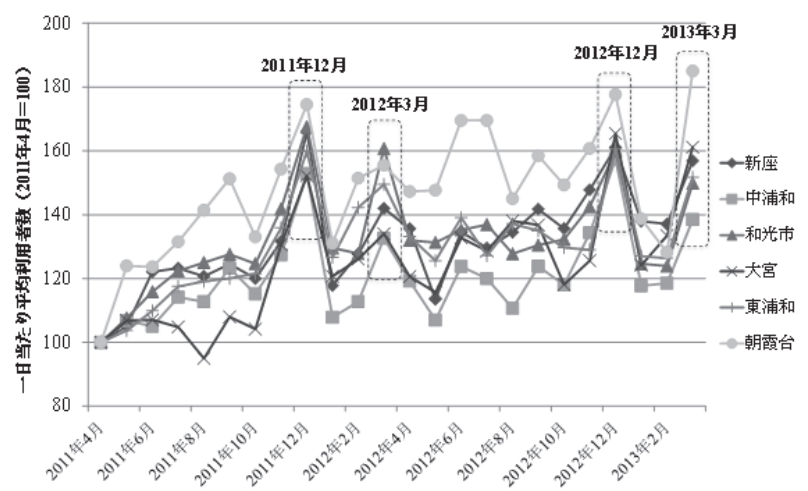

図-3 月別一日当たり平均利用者数

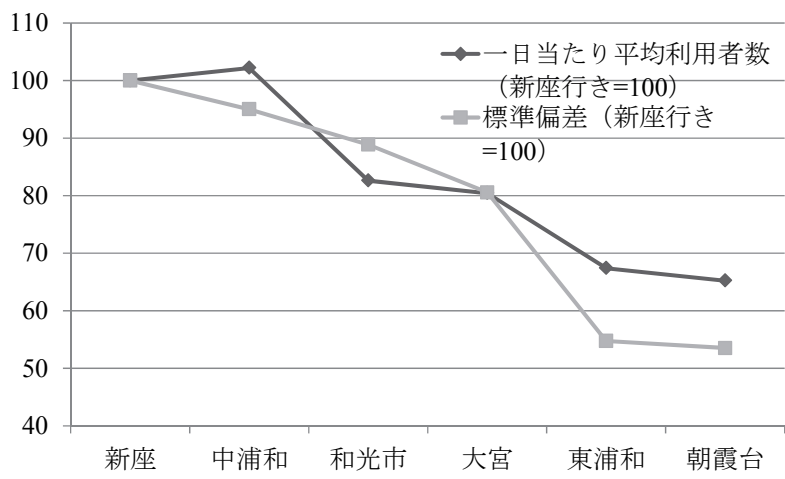

図-4 路線別利用者数と標準偏差

数を 100 として，利用者数を基準化して図示した。また 図-4では，路線別の利用者数と標準偏差について示す. こちらについても，同様の理由で，新座行きの平均利用 者数及び標準偏差を 100 として，データを基準化した.

図-2をみると，全路線共通の傾向として，曜日別では 金曜日及び祝前日の利用者が多いことが分かる．特に和 光市，大宮，中浦和行きについては，土曜日，祝前日の 利用者数が月曜日の約 2.5 倍となることが示された．金 曜・祝前日は他の日と比較して，勤務時間後に宴会や遊 びなど，どこかに立ち寄ることが多く，土曜日，祝前日 の深夜急行バス利用者数が多くなるものと考えられる. 月曜日から木曜日については，月曜日の利用者数が最少 で，木曜日にかけて利用者数は徐々に増加している. 
月別利用者数（図-3）では，3月及び12月に多いこと が分かる. 2011年4月の一日当り平均利用者数を 100 とし た2年間の平均利用者数が131.3であるのに対し，3月及び 12月はそれぞれ $151.4 ， 162.9$ となり，3月と12月が深夜急 行バスの繁忙期であることが分かる．また，利用者数が 最も少ない月は1月で，124.1であった。

図-4を見ると，路線別に利用者数変動の程度が異なる ことが分かる．新座行きについては，2年間の路線別平 均利用者数と標準偏差が全路線で最大である. 以下，中 浦和, 和光市, 大宮, 東浦和, 朝霞台行きの順に利用者 数と標準偏差は小さくなる. 以上より, 利用者数の標準 偏差が最大である新座行きの利用者数及ひ配車台数予測 が他路線よりも比較的難しいものであると見込まれる.

また, 天候別（降水の有無別）の一日当り平均利用者 数については, 雨天時と晴天時で比較すると, 晴天時が 約3名多く, 大規模イベント開催時は，それ以外の日よ りも平均利用者数が約 5 名多くなった.

\section{(3) アンケート調査}

深夜急行バス利用者数への影響要因を検討するために, 文献調查及び利用者数データを用いた基礎的分析に加え, 対象路線の始発バス停である池袋駅において，2013年12 月17日火曜日（運行日上は，16日月曜日）に，深夜急行 バス利用者47名を対象にインタビュー形式でのアンケー 卜調査を行った。なお天候は晴れで，主な設問としては 利用が多い曜日及び月とその理由，利用が少ない曜日及 び月とその理由, 利用決定要因, 利用決定時期, 利用頻 度である。

図-5に曜日別及び月別の最多・最少利用日の結果を示 す. 曜日別利用日は金曜日が $66.7 \%$ （31人）で最多であ った．これは図-6で示している通り，週末である金曜日 は深夜まで飲み会や遊びに興じる人が多いためである. また，仕事が深夜まで長引いたことによって梁夜急行バ スを利用した人も $20 \%$ 近くを占めた。 また月曜日が最多 利用日の約 $20 \%$ 占め，基礎集計とは相反する結果とな ったが，これはアンケート実施日が月曜日であることが 影響しているものと考えられる. 最多利用曜日を月曜日 と回答した乗客の利用理由については, アンケート回答 者の休日が火曜日であるため, 月曜日は職場での飲み会 が多く, 帰宅が深夜になることが多いとの回答が半数を 占めた，つまり，各個人の休日の前日に飲み会などを予 定し, 帰宅時間が深夜になることで深夜急行バスの需要 が発生しているものと考えられる.

なお，金曜日以外の利用理由（図-6）についても，飲 み会が最多となった，ただし，その回答割合は66.7\%で， 金曜日の割合よりも小さい，その減少分により，その他 が15\%程度増加しているが，その内訳としては，「座っ て帰宅できる」や「タクシーより安価」などの理由があ
つた．最少利用曜日については，月曜日と水曜日が $23.5 \%$ で最少となった。 また図-5より, 最多利用月は 12 月が79\%と最多であった。

図-6より，金曜日における深夜急行バス利用理由と同 じく, 12月は飲み会によって帰宅時間が遅くなることが 示唆される. 12月は年末で忘年会が多いため, 妥当な結 果である. 一方で，12月以外では飲み会・遊びの回答割 合は約30\%で，仕事が多忙であることによって州宅時間 が深夜になり, 深夜急行バスの利用が増加することが示 唆される．なお，仕事が多忙であることにより深夜急行 バスを利用する乗客は3月が最多であることがアンケー 卜調査より明らかになった. 最少利用月については, 1 月が最多であった.

深夜急行バスの利用を決定しているタイミングについ ては，直前になって決定している割合が93\%に上り，そ のうち $80 \%$ が鉄道の最終電車後であった. この結果より, 深夜急行バスは計画的に利用されている交通機関ではな く, タクシーのように直前に乗車が決定されることが明 らかとなった。 また, タクシーとの選択において, 深夜 急行バスを選択する理由として，ほぼ $100 \%$ の人がタク シーより安価であることを挙げている.

以上より, 深夜急行バスの利用理由は, 主に飲み会や 仕事が多忙であることに起因し, 帰宅時間が遅くなるこ とが理由であることが分かった，12月と3月は，特に飲

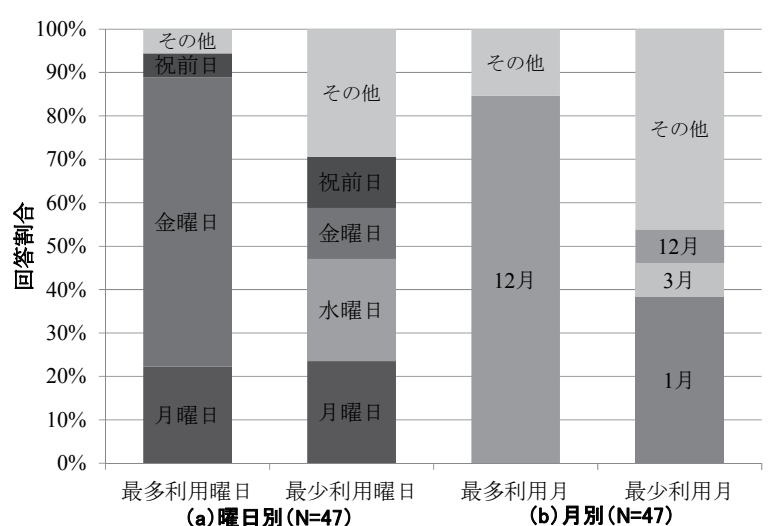

図-5 最多・最少利用曜日と最多・最少利用月の割合

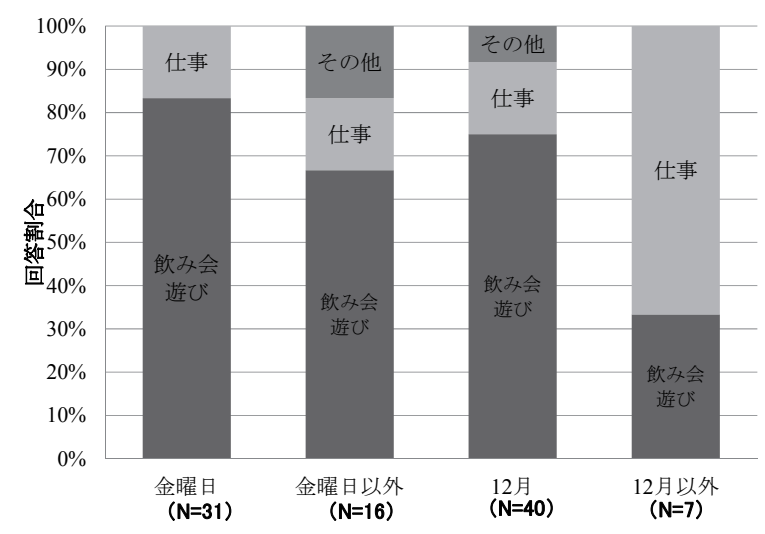

図-6 曜日・月別の利用理由 
み会が利用理由となっており，それ以外の月では，仕事 で䚻宅時間が遅くなったことによって利用割合が上昇す ることが分かった。

\section{NNを用いた利用者数の予測}

\section{(1) 予測方法}

本章では，前章までに行った文献調查，基礎集計，ア ンケート調查より, 深夜急行バス利用者数に影響を与え ると考えられる要因を入力值として, NN を用いて深夜 急行バス利用者数予測を行う. NN は, 外部から数值な どの情報を受け取る入力層，入力層もしくは下位の中間 層から信号を受け取り, 出力層あるいは上位の中間層に 数值などの情報を送る中間層, ネットワークの外部に信 号を送る出力層の 3 つから構成される多層パーセプトロ ンである ${ }^{10}$. ただし，モデルによっては中間層が構成さ れない場合もある ${ }^{10}$. 本研究では, 入力值として, 利用 者数データの基礎分析及びアンケート調査の結果に基づ き，利用者数に影響を及ぼすと考えられる月・水・金曜 日と祝前日, $1 \cdot 3 \cdot 12$ 月, 降水確率 $(1$ 週間前予測) お よび降水量（実績值），イベントの有無を設定した。 大 規模イベント開催時は, 発生トリップ数が多くなり, 深 夜急行バスにも影響が出るものと考え，さいたま市及び 横浜市で開催されたサッカー日本代表の試合日と, 東京 ドーム及び日本武道館でのコンサート開催日を対象とし て，イベントの有無を考慮した。教師信号には，2011 年 4 月から 2013 年 3 月までの実利用者数, 出力值には 各路線の利用者数を設定してモデル構築を行った.

なお, インタビュー調査より, 配車計画は1週間前に 完了寸る必要があると分かっている．したがって，運行 1週間前に入手可能なデータを入力值として予測を行っ た（運行1週間前モデル）。降水に関するデータについ ては，運行1週間前は降水確率のみ入手可能であるため, 降水確率を入力值とした. また, 運行当日の降水量を入 力值としたモデルについても，比較対象として示す．モ デルの妥当性については，モデルから推定した予測值と 実測值について, 式(1)に示す最少誤差二乗法（RMSE） を用いることで評価した，RMSEは予測誤差の標準的な 大きさを示寸指標であり，值が小さいほど予測誤差が小 さいことを意味する.

$$
R M S E=\sqrt{\frac{1}{n}\left(q_{i r}^{E}-q_{i r}^{A}\right)}
$$

$q_{i r}^{E}$ はモデルによる路線 $r$ の運行日iの利用者数の推定值, $q_{i r}{ }^{A}$ は路線 $r の$ 運行日 $i$ 利用者数の実測值, $n$ はサンプル
数である.また， NNでは出力值に影響を与えている修 正結合荷重 $\left(\Delta W_{i j}\right)$ は式(2)のように表される.

$$
\Delta W_{i j}=\varepsilon\left(t_{i}-o_{j}\right) \alpha_{i}
$$

$\varepsilon$ は正の定数， $t_{i}$ は教師信号（2011年4月～2013年3月の各 路線の利用者数データ）， $o_{j}$ は出力層での出力値 (2011 年4月～2013年3月の各路線における利用者数の推定值）， $a_{i}$ は中間層での出力值である.

\section{(2) 予測結果と考察}

構築したモデルに基づき, 運行 1 週間前モデルと運行 当日モデルから出力した各推定值と実績值との RMSE を図-7に示す。

図-7 より, 利用者数の標準偏差が大きい路線ほど RMSE の值が大きく, 予測精度が低下寸る傾向にある.

これは需要が安定している路線ほど予測精度が高いこと を示している．以上より，モデル推定の結果については， 各路線の需要の安定性がモデルの精度に影響していると 考えられる.

運行 1 週間前と運行当日の RMSEを比較すると, 和光 市行き，東浦和行きを除き，予測精度は当日モデルの方 が若干高い結果となったが，その差は小さい。これにつ いては，深夜急行バスの利用要因として，金曜日や祝前 日，3 月や 12 月の影響が大きく, 両モデルで入力值が 異なる降水の影響がほとんど反映されなかったことによ るものと考えられる.

次に, 各入力值が深夜急行バス利用者数に与える影響 について考察するため, 式(2)より得られた修正結合荷 重を図-8に示寸．なお，1月，水曜日，イベントの有無 は重み係数の值が小さく, 利用者数にほとんど影響を与 えないことから, 図の煩雑性を避けるため除外した. 図 -8 より, 東浦和行きを除く全路線で金曜日及び祝前日 の值が大きく，利用者数に正の影響を与えることが分か

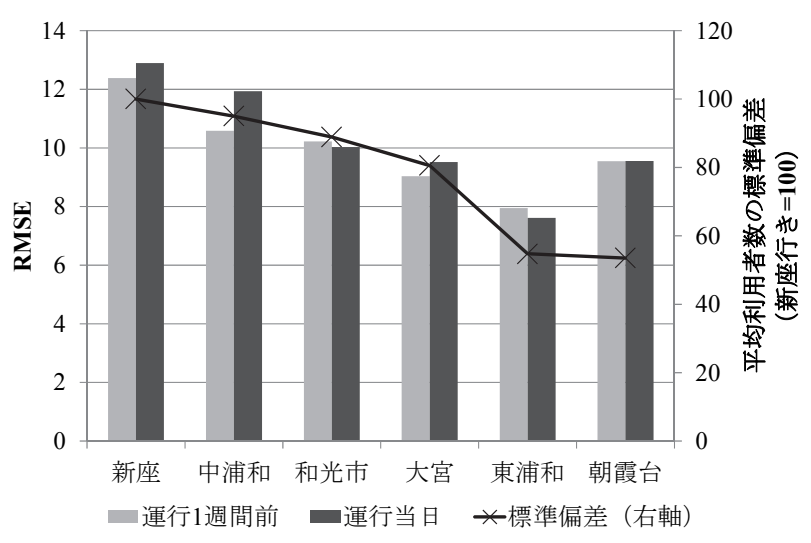

図-7 利用者数予測の結果 


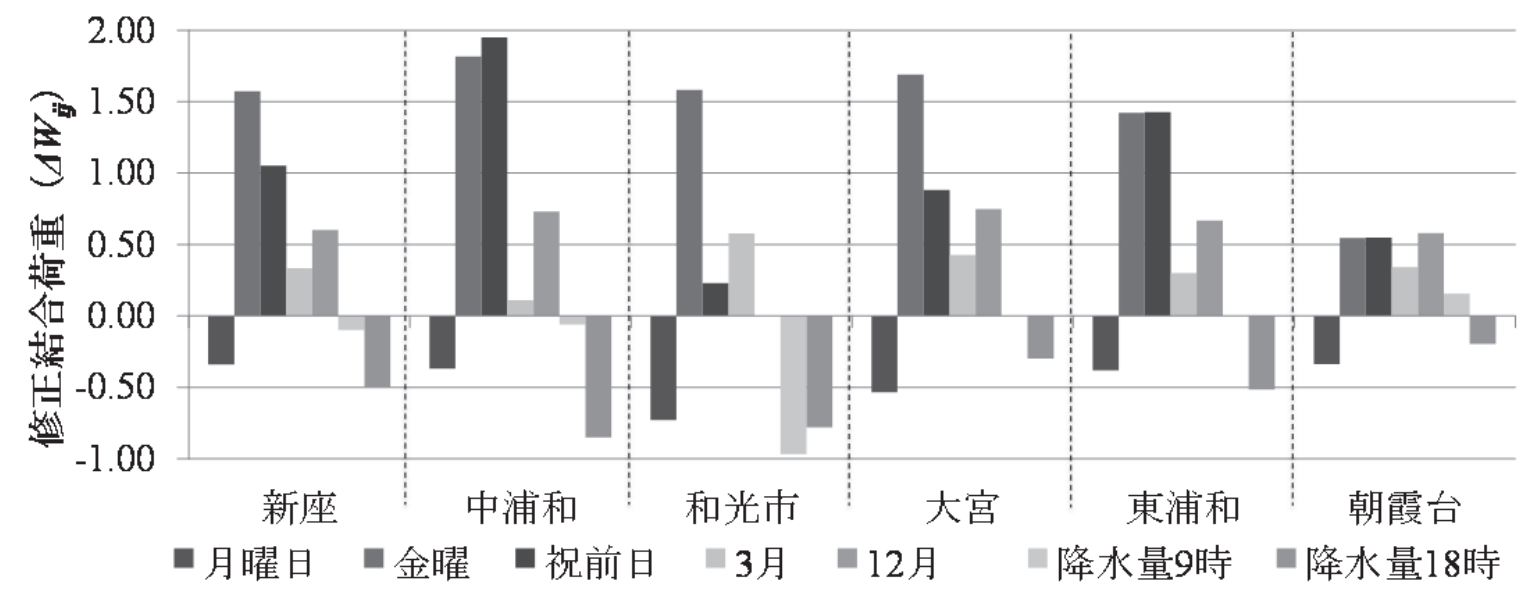

図-8 入力值の重み係数

る. 特に，朝霞台行きを除く全路線で金曜日の修正結合 荷重が 1.5 程度となり，3 月と 12 月の影響と比較して, 利用者数に約 2 倍の影響を与えることが分かる. 祝前日 についても，金曜日と同様の傾向を示しているが，和光 市，大宮，朝霞台行きでは，利用者数への影響力が小さ い. また, 月曜日については全路線で負の值となってお り，利用者数に負の影響を与えることが分かる. 月曜日， 金曜日，祝前日については，基礎集計と同様の傾向を示 しており, 妥当な結果といえる.

降水量については負の值となり, 基礎集計の結果と同 様に, 利用者数を減少させる要因であることが分かる. また, 9 時の降水状況と比較して, 18 時の降水量の影響 が強いことも分かった. この理由としては, アンケート 調査より, 帰宅時に雨が降っていると, 鉄道を利用して 比較的早い時間に帰宅し，家族などに自宅最寄り駅まで 迎えに来てもらう行動を取るためである. 深夜急行バス で帰宅すると，自宅最寄りバス停への到着が深夜となり， 家族の迎えが難しくなるため, 降雨時は深夜急行バス利 用者が減少するものと考えられる.

予測精度について示唆を得ることを目的として，予測 誤差が大きい運行日を抽出し，その要因を考察する. 全 期間において誤差が最大であったのは 2012 年 11 月 30 日（金曜日）であった。同日は対象運行日中，新座，和 光市, 中浦和, 朝霞台行きの平均利用者数が 89 人と最 多であった. その理由として, 埼京線や湘南新宿線が 23 時過ぎまで遅延していたことが影響していると考え られる. ある程度競合している鉄道路線の運行障害によ り, 深夜急行バスが代替交通機関として機能したものと 考えられる.

新座行き及び中浦和行きに関しては，2013 年 1 月 11 日（金曜日）が最大誤差日であった。 なお，新座行きの 予測值は 72 人であったのに対し，実測值は 140 人とな り，中浦和行きについては予測值が 75 人で，実測值は 134 人であった. 同日は鉄道の運行障害はなく, 年始の
金曜日であることから，新年会による影響と考えられる なお，1月の平均利用者数は月別では最少であるものの， 標準偏差は 12 月に次いで大きい值である.これより， 1 月は平均的に利用者数が少ないが，新年会などの影響に より，急激に利用者が増加する可能性があることを示唆 している.

和光市行きについては，2012 年 5 月 25 日（金曜日） において，予測值が 64 人であるのに対し，実績值が 132 で最大誤差日であった. 同日は, 山手線が 22 時頃か ら 30 分程度運転を見合わせていた。 これが影響し, 山 手線で遅れた人が目的の鉄道路線に乗り継げず，深夜急 行バスを利用したものと考えられる.

大宮行きについては，2011 年 9 月 16 日（金曜日）に おいて, 予測值が 61 人であるのに対し, 実利用者数は 29 人に留まり, 最大誤差日となった. 当該日は利用者 数が 29 人と平均よりも 15 人程度少なかったが，これは 9 月 21 日に関東地方に台風が直撃する予報が発表され たことにより，定時とともに帰宅した人が多かったため と考えられる.

以上より，鉄道の運行状況，年末年始の宴会に加え， 台風などの突発事象をモデルに考慮することで, 利用者 数の予測值の精度を向上させることが可能と考えられる. しかしながら，鉄道の運行障害や台風などの突発事象は, バスの配車計画を完了させる 1 週間前には予測不可能で ある. そのため, 配車計画には反映できないという課題 がある.

\section{5. バス配車台数の効率性向上の検討}

深夜急行バスの配車台数の効率化を目的として, NN による利用者数予測の結果に基づき, バスの必要配車台 数の推定を行い, 実利用者数データに基づくバスの配車 台数と比較する. 両者の配車台数が同数である場合, バ 
スの配車台数予測は的中したとする.つまり, 運行日 $i$ における路線 $r$ の予測必要台数を $V_{i}^{E}$, 実際の必要台数 を $V_{i r}^{A}$ とすると, 式(3)を満足するとき，バスの配車台数 予測は的中したと定義する.

$$
V_{i r}^{E}=V_{i r}^{A}
$$

予測必要台数 $V_{i r}^{E}$ については, NN で推定される利用者 数推定值 $q^{E}{ }_{i r}$ を用いて, 式(4)の関係から決定される.

$$
V_{i r}^{E}=\left\{\begin{array}{ccc}
1 & q_{i r}^{E} \leq 70 & (i=1,2,3, \cdots, 493) \\
2 & 70 \leq q_{i r}^{E} \leq 140 & (r=1,2,3, \cdots, 493) \\
3 & q_{i r}^{E}>140 &
\end{array}\right.
$$

本研究で対象とする運行日 $i$ は 493 日で, 対象路線数 $r$ は 6 路線である. また, インタビュ一調査より, バス 1 台の定員は 70 名であることが分かっている．したがっ て，1 台当たり 70 名を最大乗客数としてバスの配車台 数を決定した. 以上より， $\mathrm{NN}$ による深夜急行バス利用 者数の予測值 $q_{i r}^{E}$ が 70名以下, 71 140名, 141名以上の 場合は，バスの配車台数はそれぞれ 1 台，2 台，3 台と 予測される. 実際の必要台数 $V_{i r}^{A}$ は, 利用者数の実測値 $q_{i r}^{A}$ 用いて式(5)から決定される.

$$
V_{i r}^{A}=\left\{\begin{array}{ccc}
1 & q_{i r}^{A} \leq 70 & (i=1,2,3, \cdots, 493) \\
2 & 70 \leq q_{i r}^{A} \leq 140 & (r=1,2,3, \cdots, 493) \\
3 & q_{i r}^{A}>140 &
\end{array}\right.
$$

全路線（ $r=1 \sim 6 ）$ ，全対象期間（i=1〜493）における 予測利用者数 $q_{i \text { ir }}^{E}$ と実利用者数 $q_{i r}^{A}$ を図 -9 に示寸．バス の配車計画は運行 1 週間前に決定する必要があるため, 運行 1 週間前に入手可能なデータに基づいて推定した予 測利用者数を示している. なお，乗客が 140 名以上の乗 車日は実績值で一日のみ (2013 年 1 月 11 日（金曜日） の新座行き）で，予測值では 140 名以上の運行日は存在 しなかった，図-9 において，太字の破線で囲まれてい る範囲は式(3)を満足していることを示しており，予測 必要台数と実必要台数が一致し, 予測が的中した運行日 である.

全路線の実データにおいて，必要台数が的中した運行 日は対象期間内の 2,958 件（=493 運行日*6 路線）中 2,649 件で, 的中率は $89.6 \%$ であった. 本研究で構築した モデルを用いた場合，式(3)を満足した件数は 2,832 件と 183 件改善し，的中率は $95.7 \%$ となった。

配車台数が的中しなかった件数は 126 件であった。 そ
のうち 53 件は予測必要台数が 2 台, 実必要台数が 1 台 で，平均 6.4 名の過大予測であった. 残りの 73 件は予測 必要台数が 1 台, 実必要台数が 2 台で, 平均 10.2 名の過 小予測であった。 このように, 配車台数が的中しなかっ た運行日では, 予測必要台数が実必要台数よりも不足す る件数が多く，その誤差も大きい傾向がみられた。

路線別の予測必要台数と実際の配車台数の的中率及び 予測必要台数と実際の配車台数の的中率の差を図-10に 示寸. 利用者数の標準偏差が最も大きい新座行きでは, 実際の配車台数と予測必要台数の的中率が共に $97.3 \%$ で, 的中率の改善はみられなかった。しかしながら, 利用者 数の標準偏差が小さくなる中浦和，和光市，和光市，大 宮, 東浦和行きの順に的中率の差が拡大している. これ より, 利用者数の標準偏差が小さく, 需要が安定してい る路線ほど非効率日の効率化は達成されることが示され た.

利用者数の標淮偏差が最も小さい朝霞台行きでは，実 際の非効率日は 2 件でもともと的中率が高く $(99.6 \%)$, 的中率の改善は見られなかった。 この 2 件の非効率日に ついては, 4.(2)で述べた通り, 鉄道路線の運行障害が影

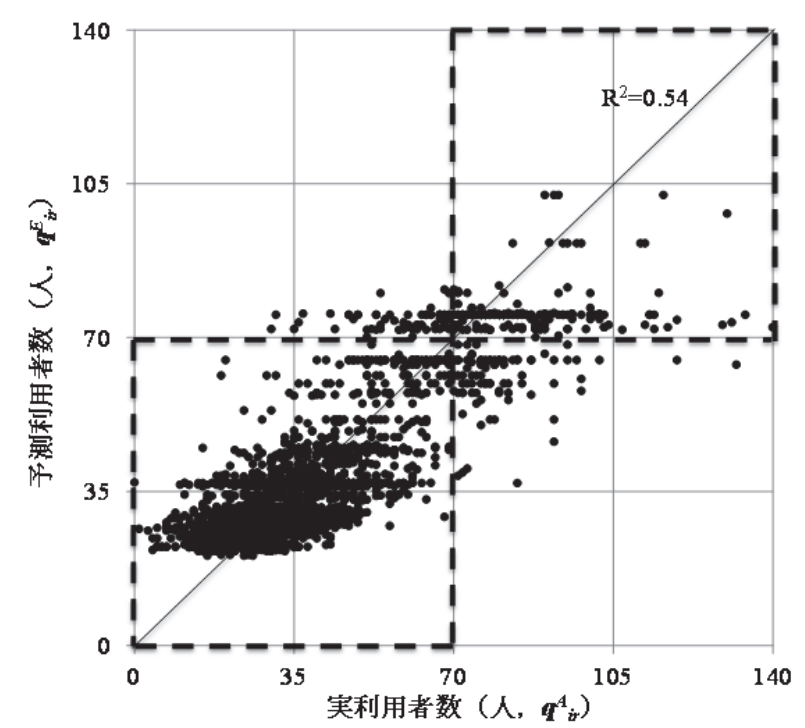

図-9 予測利用者数と実利用者数

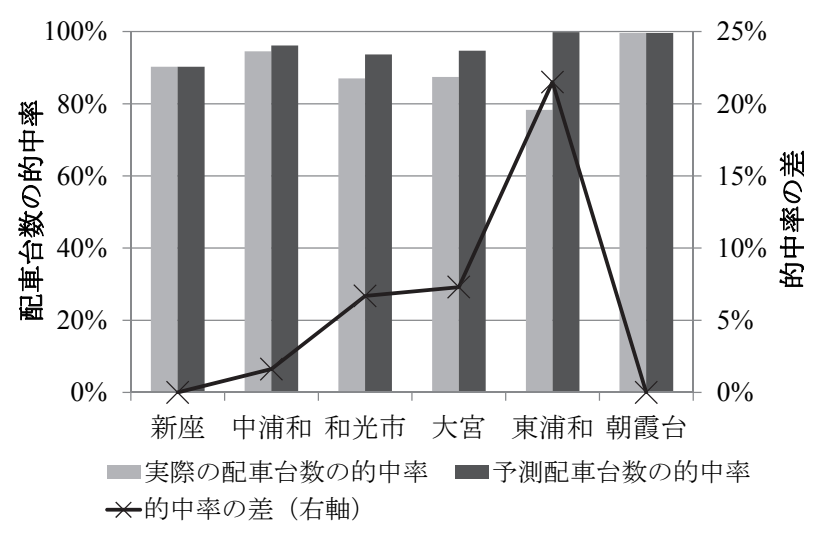

図-10 路線別配車台数の的中率 
響している.

以上より，金曜・祝前日は 2 台，それ以外の曜日は 1 台の配車という現状のバス配車計画と比較して, 本研究 で提案したニューラルネットワークを用いた予測手法は 配車台数の的中率を上昇させているため, バスの効率的 配車に資するといえる．したがって，実務においては慣 例的にバス台数を配車するのではなく, 本研究で提案し たニューラルネットワークを用いた予測手法を用いて利 用者数を予測し，その予測值に基づいてバスの配車台数 を決定することにより， バス台数の効率的配車が可能に なるものと考えられる. ただし，今後の課題として，図 -8 より, 70 人を区切りにして配車台数を決定している ため, 70 人前後の予測精度を向上させることができれ ば，台数予測の精度向上が向上寸るものと考えられる.

\section{6. おわりに}

本研究では, 利用者数データの基礎集計とアンケート 調査に基づき利用者の深夜急行バス利用要因を検討し， ニューラルネットワーク（NN）を用いた短期的な利用 者需要予測モデルを構築した。構築したモデルより利用 者数を予測し, 需要が比較的安定している路線ほど予測 が的中しやすい傾向が示された，さらに，需要予測に基 づいてバスの配車台数を算出し，バス事業者の既存の配 車方法で発生していた非効率日がどの程度効率化される のかを検討した．その結果，バス事業者による配車方法 の的中率は $89.6 \%$ であったものが，本研究で提案する予 測モデルに基づく配車台数の的中率は 95.7\%まで上昇し た.これにより， NNによる利用者数予測に基づくバス の配車台数計画は有用であることを示寸ことができた.

また, 需要が安定している路線ほど非効率日の効率化は 達成されや寸いことが示された.

今後の課題としては, 深夜急行バスの利用要因分析を 深度化し，予測モデルを精緻化することが挙げられる． 例えば, 深夜急行バス事業者へのインタビュー調査によ ると，ある程度競合する鉄道のダイヤ乱れや，スポーツ イベントやコンサートなどの大規模イベント時には利用 者数は増加するとのことであった，また，予測誤差の大 きかった運行日には鉄道の運行障害が目立った.しかし 今回の分析では, 鉄道の運行状況を示すデータを取得で きなかったため，モデルで考慮できていない，鉄道の運 行状況を考慮できれば，予測精度はさらに向上するもの と考えられる. また，アンケート調査についても，月曜 日だけでなく, 利用者の多い金曜日や祝前日に行うこと が必要である。
タビュー調査にご協力いただきました．なお本研究は, 日本大学理工学部シンボリックプロジェクト研究の支援 を受けています。ここに謝意を表します。

\section{参考文献}

1) 森地茂, 兵藤哲朗, 島村喜一: 首都圈深夜交通の実 態分析とその政策課題, 土木計画学研究・論文集, No. 9, pp. 85-92, 1991.

2) 倉㴊健介, 浅野光行: 深夜急行バスにみる媣夜交通 サービスの評価に関する研究, 土木計画学研究・講 演集, No.36, pp.124-128, 2007.

3) McCord, M. R. and Cheng, L-H. : Day-of-week and partof-month variation in bus ridership: Empirical Results, Journal of Transportation Research Record, No. 1078, pp. 17-22, 1986.

4) 杉恵頼寧, 芦沢哲蔵, 古藪篤人：個人の発生トリッ プの曜日変動，都市計画論文集，No. 24，pp. 307-312， 1989.

5) 杉恵頼寧, 芦沢哲蔵: 買物・使用交通の矅日変動特 性, 日本都市計画学会学術研究論文集, Vol. 26, No. 47, pp. 277-282, 1991.

6) Zhang, K. and Taylor, M. A. P. : Towards universal freeway incident detection algorithms, Transportation Research Part C: Emerging Technologies, Vol. 14, No. 2, pp. 68-80, 2006.

7) Zhan, G., Wilson, N. H. M. and Rahbee, A. : Impact of weather on transit ridership in Chicago, Illinois, Journal of Transportation Research Record, No. 2034, pp. 3-10, 2007.

8) 中沢航大, 佐々木邦明: 高速道路利用データを活用 した高速道路の短期的需要変動に関する研究, 交通 工学研究会発表会論文集, Vol. 31, No. 52, pp. 267270, 2011.

9）高山純一, 塩土圭介：公共交通計画から見た通勤者 の交通手段変更の実態に関寸る研究, 土木計画学研 究・論文集, No. 15, pp. 517-525, 1998.

10) 本村陽一：ベイジアンネットワーク入門からヒュー マンモデリングーの応用まで, 日本行動計量学会第 7 回春のセミナー, 2004.

11) 福水健次 : ニューラルネットの推定理論—モデルの 対称性と識別不能性一, 応用統計学会・日本計量生 物学会合同年次大会, pp. 1-12, 2001

12) Chiang, W. C., Russel, R. A. and Urban, T. L. : Forecasting ridership for a metropolitan transit authority, Transportation Research Part A: Policy and Practice, Vol. 45, No. 7, pp. 696-705, 2011.

13）村野剛教, 代田孝広, 桑原雅夫, 大口敬: 高速道路 の交通事故発生予報手法, 東芝レビュー, Vol. 67, No. 12, 2012.

14）奥嶋政嗣, 大窪剛文, 大藤武彦: ニューラルネット ワークを用いた都市高速道路における時系列流入時 系列交通量予測の適用性の検討, 土木計画学研究 講演集, Vol. 25, No. 2, CD-ROM, 2002.

15）佐々木恵一, 田村亨, 桝谷有三, 斎藤和夫: ニュー ラルネットワークを用いた観光周行動の基礎的分析, 日本都市計画学会学術研究論文集, Vol. 31, No. 62, pp. 367-372, 1996. 


\title{
SHORT-TERM DEMAND FORECASTING FOR THE EFFECTIVE VEHICLE ALLOCATION OF MIDNIGHT BUS
}

\author{
Tomoya KAWASAKI, Tomoyuki TODOROKI, Tetsuya IWASAKI \\ and Hiroaki NISHIUCHI
}

The demand on passenger of midnight bus is highly fluctuated. Thus, vehicle allocation of the midnight bus is sometimes ineffective because of over-supply (less-supply) during the day with small (high) demand. In this case, several negative impact is expected such as increase of user's unsatisfaction level due to the congestion of the bus and decrease in profit of bus companies due to the less-supply of the bus allocation. In this study, we attempt (i) to reveal factors to affect the use of midnight bus by questionnaire surveys, (ii) to forecast the number of bus allocation cased upon short-term demand forecasting of midnight bus, and (iii) to discuss whether effectiveness of bus allocation is improved by using model developed. The demand of passenger is forecasted by employing Neural Network. The forecasting accuracy is improved for the route of smaller variability of passenger demand. As a result, while a hitting ratio of proper vehicle allocation of actual data is $89.6 \%$, the model developed in this study increases a hitting ratio up to $95.7 \%$. From this result, the model developed in this study is effective to increase the effective vehicle allocation of midnight bus. As a future work, factors of the operation of the train should be considered. Among the unpredicted operational days, most of them are caused by train operational troubles. Since this study could not consider the factors on the situation of train operation, it could be increased the forecasting accuracy. 